\title{
The relation of mean platelet volume and platelet distribution width levels with the severity of preeclampsia
}

\author{
Semra Oruç Koltan', Burcu Artunç Ülkümen', Halil Gürsoy Pala² \\ ${ }^{1}$ Department of Obstetrics and Gynecology, Faculty of Medicine, Celal Bayar University, Manisa, Turkey \\ ${ }^{2}$ Department of Obstetrics and Gynecology, Health Sciences University Tepecik Training and Research Hospital, Izmir, Turkey
}

\begin{abstract}
Objective: We aimed to evaluate the alterations of platelet indices such as mean platelet volume and platelet distribution width in preeclampsia and normotensive pregnant women.

Methods: This retrospective evaluation consisted of 45 preeclamptic pregnancies and 50 healthy singleton normotensive pregnancies matched for the maternal age and week of gestation admitted to our clinic between January 2012 and June 2013. The data regarding the hemoglobin level, platelet count, mean platelet volume, and platelet distribution width were analyzed.

Results: Mean platelet count was $194.450 \pm 67.240 / \mathrm{mm}^{3}$ and $232.860 \pm 65.260 / \mathrm{mm}^{3}$ in preeclamptic and control groups, respectively $(\mathrm{p}=0.029)$. Mean platelet volume values were $10.20 \pm 1.25$ and $9.91 \pm 1.95 \mathrm{fL}$ in preeclamptic and control groups, respectively $(\mathrm{p}=0.04)$. Mean platelet distribution width values were $16.54 \pm 0.71$ and $16.42 \pm 1.99$ in preeclamptic and control groups, respectively $(\mathrm{p}=0.650)$. Mean platelet volume and platelet distribution width values were inversely related with platelet counts $(\mathrm{p}<0.05)$. There was a correlation, but not very strong, between mean platelet volume values and mean arterial pressure. Mean platelet volume value was correlated with proteinuria, and so with the severity of preeclampsia $(\mathrm{p}<0.05)$. Platelet distribution width values were also significantly correlated with proteinuria $(\mathrm{p}<0.05)$.
\end{abstract}

Conclusion: Mean platelet volume and platelet distribution width values are increased with the severity of preeclampsia.

Keywords: Preeclampsia, platelet, mean platelet volume, platelet distribution width.

\section{Özet: Preeklampsinin ağırlığı ile ortalama trombosit hacmi ve trombosit dağılım genişliği ilişkisi}

Amaç: Çalışmanın amacı preeklamptik ve normotansif gebelerde ortalama trombosit hacmi ve trombosit dağılım genişliği gibi trombosit indekslerinin değişimini değerlendirmektir.

Yöntem: Kliniğimize 2012 Ocak ile 2013 Haziran arasında başvuran, anne yaşı ve gestasyonel hafta olarak eşleştirilmiş 45 preeklamptik ve 50 sağlıklı normotansif tekil gebe çalışmaya retrospektif olarak dahil edildi. Hemoglobin seviyeleri, trombosit sayıları, ortalama trombosit hacmi ve trombosit dağılım genişliği verileri değerlendirildi.

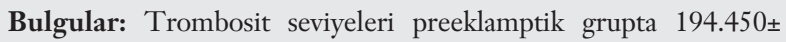
$67.240 / \mathrm{mm}^{3}$ ve normotansif grupta $232.860 \pm 65.260 / \mathrm{mm}^{3}$ olarak bulundu $(\mathrm{p}=0.029)$. Ortalama trombosit hacmi değerleri preeklamptik grupta $10.20 \pm 1.25$ ve normotansif grupta $9.91 \pm 1.95 \mathrm{fL}$ olarak tespit edildi ( $\mathrm{p}=0.04)$. Trombosit dağılım genişliği değerleri preeklamptik grupta $16.54 \pm 0.71$ ve normotansif grupta $16.42 \pm 1.99$ olarak gözlen$\mathrm{di}(\mathrm{p}=0.650)$. Ortalama trombosit hacmi ve trombosit dağglım genişliği değerlerinin trombosit değerleri ile ters olarak ilişkili olduğu izlendi $(\mathrm{p}<0.05)$. Ortalama trombosit hacmi ve ortalama arter basinc1 arasında çok güçlü olmasa da korelasyon olduğu izlendi. Ortalama trombosit hacmi değerlerinin proteinüri ve preeklampsinin ağırlığ1 ile korele olduğu gözlendi $(\mathrm{p}<0.05)$. Trombosit dağılım genişliği değerlerinin ayrıca proteinüri ile korele olduğu tespit edildi $(\mathrm{p}<0.05)$.

Sonuç: Ortalama trombosit hacmi ve trombosit dağılım genişliği değerleri preeklampsinin ağırlığı ile artmaktadır.

Anahtar sözcükler: Preeklampsi, trombosit, ortalama trombosit hacmi, trombosit dağılım genişliği.

tality with an incidence varying from $2 \%$ to $8 \%$ depending on the selected population. ${ }^{[1]}$ The delivery of the placenta is the only therapy. ${ }^{[2]}$ Especially remote from term,

\section{Introduction}

Preeclampsia is still a leading cause of maternal morbidity and mortality as well as perinatal morbidity and mor-

\footnotetext{
Correspondence: Halil Gürsoy Pala, MD. Department of Obstetrics and Gynecology, HSU Tepecik Training and Research Hospital, Izmir, Turkey. e-mail: gursoypala@yahoo.com Received: December 6, 2016 ; Accepted: December 20, 2016

Please cite this article as: Oruç Koltan S, Artunç Ülkümen B, Pala HG. The relation of mean platelet volume and platelet distribution width levels with the severity of preeclampsia. Perinatal Journal 2016;24(3):162-165.

Available online at: www.perinataljournal.com/20160243009 doi:10.2399/prn.16.0243009 QR (Quick Response) Code: 
proper timing of delivery is very important. Due to the uncertain pathologic mechanism and challenging obstetrical complications, recent studies focused on new possible biomarkers for the prediction of preeclampsia earlier rather than enhancing the pregnancy outcomes. ${ }^{[3-8]}$

Complete blood count $(\mathrm{CBC})$ is a routine test which gives information also about the platelet indices such as mean platelet volume (MPV) and platelet distribution width (PDW). Platelet consumption, increased platelet turnover and sustained inflammation during the preeclampsia development may cause some alterations in platelet indices as well as the platelet count. ${ }^{[8]}$ The availability and wide-spread use made the platelet indices very popular with the hope of investigating preeclampsia earlier. ${ }^{[8-10]}$ The published data regarding the use of MPV for preeclampsia prediction is controversial. ${ }^{[8-12]}$

In our study, we aimed to evaluate the platelet count, MPV and PDW values in preeclampsia and define the relation of these indices with the severity of the disease.

\section{Methods}

The study consisted of 45 preeclamptic pregnancies and 50 healthy singleton pregnancies admitted to our clinic between January 2012 and June 2013. The diagnosis of preeclampsia was made on the hypertension after 20 weeks of gestation (systolic blood pressure $\geq 140 \mathrm{mmHg}$ and/or diastolic pressure $\geq 90 \mathrm{mmHg}$ on at least 2 occasions 4-6 hours apart) and significant proteinuria ( $\geq 300$ $\mathrm{mg}$ in 24 hours or $\geq 1+$ on dipstick). ${ }^{[10,13]}$ The mean arterial blood pressure and proteinuria were used to describe the severity of preeclampsia (systolic blood pressure $\geq 160 \mathrm{mmHg}$ and/or diastolic pressure $\geq 110 \mathrm{mmHg}$ and/or proteinuria $\geq 2 \mathrm{~g}$ in 24 hours was described as severe preeclampsia).

During the same period, control group matched for age and week of gestation was selected. Women with chronic diseases such as chronic hypertension, connective tissue disorders such as systemic lupus erythematosus, rheumatoid arthritis, vasculitis, diabetes mellitus, thrombophilia or pregnancies with multiple fetuses or congenital fetal anomaly were excluded from the study. The data regarding the maternal age, week of gestation, hemoglobin level $(\mathrm{Hb})$, platelet count, mean platelet volume (MPV), and platelet distribution width (PDW) were evaluated. The maternal blood samples were taken just after the admission to our clinic. All blood samples were collected in tubes with EDTA (potassium ethylenediaminetetraacetate) which served as the anticoagulant agent. All the blood samples were analyzed by the hematology analyzer in two hours (MINDRAY BC-6800; Shenzhen Mindray, Guangdong, China). The study was approved by the Institutional Ethics Committee.

The statistical analysis was performed by using SPSS version 20 (SPSS Inc., Chicago, IL, USA). t-test was applied to evaluate the group differences. Correlation analysis was performed in order to evaluate the relation of MPV and PDW with blood pressure and proteinuria. A two-tailed $p$ value less than 0.05 was regarded as statistically significant. The calculated statistical power was 0.75 .

\section{Results}

Forty-five pregnancies were diagnosed as preeclampsia. Fifty normotensive healthy singleton pregnancies were regarded as the control group. Mean maternal age was $29.02 \pm 5.24$ years and $27.58 \pm 5.30$ years in preeclamptic and control groups, respectively $(\mathrm{p}=0.203)$. The demographic data of the study population is shown in Table 1. The mean week of gestation was $34.97 \pm 4.28$ and $35.56 \pm 3.45$ in preeclamptic and control groups, respectively $(\mathrm{p}=0.520)$. The mean parity was $1.05 \pm 0.99$ and $0.86 \pm 0.8845$ in preeclamptic and control groups, respectively $(\mathrm{p}=0.340)$.

The platelet counts were $194.450 \pm 67.240 / \mathrm{mm}^{3}$ and $232.860 \pm 65.260 / \mathrm{mm}^{3}$ in preeclamptic and control groups, respectively $(\mathrm{p}=0.029)$. MPV values were $10.20 \pm 1.25 \mathrm{fL}$ and $9.91 \pm 1.95 \mathrm{fL}$ in preeclamptic and control groups, respectively $(\mathrm{p}=0.04)$. PDW values were $16.54 \pm 0.71$ and $16.42 \pm 1.99$ in preeclamptic and control groups, respectively $(\mathrm{p}=0.650)$ (Table 2). MPV and PDW values were inversely related with platelet counts $(\mathrm{p}<0.05)$. There was a correlation, but not very strong, between mean platelet volume values and mean

Table 1. The demographic data of the study population.

\begin{tabular}{lccc} 
& $\begin{array}{c}\text { Preeclampsia } \\
\text { group } \\
(\mathbf{n}=\mathbf{4 5})\end{array}$ & $\begin{array}{c}\text { Normotensive } \\
\text { group } \\
(\mathbf{n}=\mathbf{5 0})\end{array}$ & $\mathbf{p}$ \\
& $29.02 \pm 5.24$ & $27.58 \pm 5.30$ & 0.203 \\
Maternal age $($ mean \pm SD) & $34.97 \pm 4.28$ & $35.56 \pm 3.45$ & 0.520 \\
Week of gestation $($ mean \pm SD) & $1.05 \pm 0.99$ & $0.86 \pm 0.88$ & 0.340 \\
\hline Parity (mean \pm SD) & & &
\end{tabular}

SD: standard deviation 
arterial pressure. Mean platelet volume value was correlated with proteinuria, and so with the severity of preeclampsia $(\mathrm{p}<0.05)$. PDW values were also significantly correlated with proteinuria $(\mathrm{p}<0.05)$. Maternal age and week of gestation seem to have no association with MPV values ( $p>0.05)$. The correlation analysis is shown at the Table 3.

\section{Discussion}

The existing data about MPV values for preeclampsia prediction is controversial. Dundar et al showed that MPV values increased during the pregnancy, which was more prominent in preeclamptic women. ${ }^{[8]}$ Dilutional thrombocytopenia is responsible for the compensatory increase in MPV and PDW values. In preeclampsia, greater platelet consumption results in a prominent increase in MPV. ${ }^{[1,12]}$ However, some other authors mentioned that there was no difference in MPV values in preeclamptic and normotensive pregnancies. ${ }^{[9,10]}$ In agreement with Dundar et al., we found that MPV values were increased in preeclamptic patients. Furthermore, the MPV and PDW values were significantly correlated with the severity of the proteinuria. MPV values were further related to the blood pressure. The greater the mean arterial pressure, the greater were the MPV values. Our findings were in accordance with the suggestion that greater platelet consumption caused significant increase in MPV values.

We found that maternal age and week of gestation had no significant effect on the platelet indices. Recently, Hong et al mentioned that platelet indices such as PDW and MPV were not much affected by the age in women during the reproductive period. However, they claimed that the race and region were main determinants in their levels. ${ }^{[14]}$ Besides, MPV and PDW values were slightly increased during the pregnancy, but this was not statistically significant $(\mathrm{p}>0.05)$.

The conflicting data about platelet indices may be due to various reasons:

- Blood sample storage period: During blood storage, MPV and PDW values change in a timedependent manner. Vagdatli et al. showed an increase in MPV and a decrease in PDW values over time. ${ }^{[15]}$ In our study, all blood sampling were collected just after the admission to the hospital and all samples were analyzed in two hours.
- The anticoagulant agent in the blood sampling tube: All blood samples in our study were collected in tubes containing EDTA as the anticoagulant agent. Different anticoagulant agents may also affect the platelet indices. ${ }^{[15]}$

- The system used for measurement of MPV: Different systems may affect the results up to $40 \% .{ }^{[10]}$ In our study, all samples were analyzed with the same system. However, this may explain the conflicting data between different researchers from different centers.

- The prior medical history and inflammatory status of the subjects may also affect the results: Cardiovascular risk factors like smoking status, hypertension, dyslipidemia, diabetes affect the size of platelets. ${ }^{[16]}$ Apart from this, in inflammation via some cytokines, the platelets size and volume alter differently: in low grade inflammatory disorders, by the involvement of the large platelets in thrombi, MPV values may increase. However, in high grade inflam-

Table 2. Laboratory analysis of peripheral blood samples in preeclamptic and normotensive pregnancies.

\begin{tabular}{lcc} 
& $\begin{array}{c}\text { Preeclampsia } \\
\text { group } \\
(\mathbf{n}=45)\end{array}$ & $\begin{array}{c}\text { Normotensive } \\
\text { group } \\
(\mathbf{n}=\mathbf{5 0})\end{array}$ \\
\hline $\begin{array}{l}\text { Hemoglobin }(\mathrm{g} / \mathrm{dl}) \\
(\text { mean } \pm \text { SD })\end{array}$ & $11.06 \pm 1.51$ & $11.96 \pm 1.08$ \\
$\begin{array}{l}\text { White blood count } \\
\left(/ \mathrm{mm}^{3}\right)\left(\mathrm{mean}^{\mathrm{S} S \mathrm{SD})}\right.\end{array}$ & $12.05 \pm 4.24$ & $12.00 \pm 4.95$ \\
$\begin{array}{l}\left.\text { Platelet }\left(/ \mathrm{mm}^{3}\right)\right) \\
(\text { mean } \pm \mathrm{SD})\end{array}$ & $194.450 \pm 67.240^{*}$ & $232.860 \pm 65.260^{*}$ \\
$\mathrm{MPV}(\mathrm{fL})(\mathrm{mean} \pm \mathrm{SD})$ & $10.20 \pm 1.25^{*}$ & $9.91 \pm 1.95^{*}$ \\
$\mathrm{PDW}(\mathrm{mean} \pm \mathrm{SD})$ & $16.54 \pm 0.71$ & $16.42 \pm 1.99$ \\
\hline
\end{tabular}

${ }^{*} \mathrm{p}<0.05$; MPV: mean platelet volume, PDW: platelet distribution width, SD: standard deviation.

Table 3. Correlation analysis of MPV and PDW with the severity of preeclampsia.

\begin{tabular}{lcccccc} 
& & SBP & DBP & MAP & Proteinuria & PLT \\
MPV & $r$ & 0.374 & 0.294 & 0.351 & 0.291 & -0.303 \\
& $p$ & 0.035 & 0.103 & 0.049 & 0.006 & 0.050 \\
\hline PDW & $r$ & 0.253 & 0.298 & 0.291 & 0.473 & -0.439 \\
& $p$ & 0.162 & 0.098 & 0.106 & 0.006 & 0.012 \\
\hline
\end{tabular}

DBP: diastolic blood pressure, MAP: mean arterial blood pressure, MPV: mean platelet volume, PDW: platelet distribution width, PLT: platelet, SBP: systolic blood pressure. 
matory conditions, the consumption of the large platelets at the inflammation site cause a decrease in MPV. ${ }^{[17]}$

- The ethnic origin and region even in the same country may affect the platelet count and platelet indices. ${ }^{[14]}$

The main limitation of our study was the retrospective design. The second limitation was the sample size. Especially with greater sample size, a significant relation also between blood pressure and PDW could be probably established.

\section{Conclusion}

In conclusion, MPV and PDW were sensitive indicators of platelet consumption. Probably with a compensatory mechanism to increased platelet consumption, MPV and PDW values increased in preeclampsia.

Conflicts of Interest: No conflicts declared.

\section{References}

1. Uzan J, Carbonnel M, Piconne O, Asmar R, Ayoubi JM. Preeclampsia: pathophysiology, diagnosis, and management. Vasc Health Risk Manag 2011;7:467-74.

2. Young BC, Levine RJ, Karumanchi SA. Pathogenesis of preeclampsia. Annu Rev Pathol 2010;5:173-92.

3. Schneuer FJ, Roberts CL, Ashton AW, Guilbert C, Tasevski $\mathrm{V}$, Morris JM, et al. Angiopoietin 1 and 2 serum concentrations in first trimester of pregnancy as biomarkers of adverse pregnancy outcomes. Am J Obstet Gynecol 2014;210:345.e1-9.

4. Goel A, Rana S. Angiogenic factors in preeclampsia: potential for diagnosis and treatment. Curr Opin Nephrol Hypertens 2013;22:643-50.

5. Petla LT, Chikkala R, Ratnakar KS, Kodati V, Sritharan V. Biomarkers for the management of pre-eclampsia in pregnant women. Indian J Med Res 2013;138:60-7.
6. Polsani S, Phipps E, Jim B. Emerging new biomarkers of preeclampsia. Adv Chronic Kidney Dis 2013;20:271-9.

7. Naljayan MV, Karumanchi SA. New developments in the pathogenesis of preeclampsia. Adv Chronic Kidney Dis 2013; 20:265-70.

8. Dundar O, Yoruk P, Tutuncu L, Erikci AA, Muhcu M, Ergur $\mathrm{AR}$, et al. Longitudinal study of platelet size changes in gestation and predictive power of elevated MPV in development of pre-eclampsia. Prenat Diagn 2008;28:1052-6.

9. Altınbas S, Toğrul C, Orhan A, Yücel M, Danısman N. Increased MPV is not a significant predictor for preeclampsia during pregnancy. J Clin Lab Anal 2012;26:403-6.

10. Ceyhan T, Beyan C, Başer I, Kaptan K, Güngör S, Ifran A. The effect of pre-eclampsia on complete blood count, platelet count and mean platelet volume. Ann Hematol 2006;85:320-2.

11. Järemo $P$, Lindahl TL, Lennmarken C, Forsgren $H$. The use of platelet density and volume measurements to estimate the severity of pre-eclampsia. Eur J Clin Invest 2000;30:1113-8.

12. Hutt R, Ogunniyi SO, Sullivan MH, Elder MG. Increased platelet volume and aggregation precede the onset of preeclampsia. Obstet Gynecol 1994;83:146-9.

13. Gary C, Norman FG, Kenneth JL, Larry CG, Jonh CH, Katharine DW. Williams obstetrics. 21st ed. New York (NY): McGraw-Hill; 2001. pp. 567-618.

14. Hong J, Min Z, Bai-sen P, Jie Z, Ming-ting P, Xian-zhang H, et al. Investigation on reference intervals and regional differences of platelet indices in healthy Chinese Han adults. J Clin Lab Anal 2015;29:21-7.

15. Vagdatli E, Gounari E, Lazaridou E, Katsibourlia E, Tsikopoulou F, Labrianou I. Platelet distribution width: a simple, practical and specific marker of activation of coagulation. Hippokratia 2010;14:28-32.

16. Ihara A, Kawamoto T, Matsumoto K, Shouno S, Morimoto T, Noma Y. Relationship between hemostatic factors and the platelet index in patients with ischemic heart disease. Pathophysiol Haemost Thromb 2006;35:388-91.

17. Gasparyan AY, Ayvazyan L, Mikhailidis DP, Kitas GD. Mean platelet volume: a link between thrombosis and inflammation? Curr Pharm Des 2011;17:47-58. 